\begin{tabular}{|l|l|l||}
\hline \multicolumn{2}{|c|}{ PublisherInfo } \\
\hline \hline PublisherName & $:$ & BioMed Central \\
\hline \hline PublisherLocation & $:$ & London \\
\hline \hline PublisherImprintName & $:$ & BioMed Central \\
\hline \hline
\end{tabular}

\title{
Proteome purification
}

\begin{tabular}{|l|l|l||}
\hline \multicolumn{2}{|c|}{ ArticleInfo } \\
\hline \hline ArticleID & $:$ & 4418 \\
\hline \hline ArticleDOI & $:$ & $10.1186 /$ gb-spotlight-20020308-01 \\
\hline \hline ArticleCitationID & $:$ & spotlight-20020308-01 \\
\hline \hline ArticleSequenceNumber & $:$ & 84 \\
\hline \hline ArticleCategory & $:$ & Research news \\
\hline ArticleFirstPage & $:$ & 1 \\
\hline \hline ArticleLastPage & $:$ & 2 \\
\hline \hline & & RegistrationDate : 2002-3-8 \\
\hline ArticleHistory & $:$ & OnlineDate \\
\hline \hline ArticleCopyright & $:$ & BioMed Central Ltd2002-3-8 \\
\hline \hline ArticleGrants & $:$ & \\
\hline \hline ArticleContext & $:$ & 130593311 \\
\hline \hline
\end{tabular}




\section{Jonathan B Weitzman}

Email: jonathanweitzman@hotmail.com

In the March 5 Proceedings of the National Academy of Sciences, Braun et al. describe a methodology to perform high-throughput purification of human proteins using several affinity-tags (Proc Natl Acad Sci USA2002,99:2654-2659). They exploited the Gateway recombinational cloning system that employs a versatile 'master' vector for easy transfer into different expression vectors. They chose a test set of 32 human genes and expressed them in four different vectors with different affinity tagsL: the His6tag, calmodulin-binding peptide, glutathione- $S$-transferase or maltose-binding protein. Using different denaturing and nondenaturing purification conditions they were able to isolate around $80 \%$ of expressed proteins. Braun et al.demonstrated that the system can be easily scaled-up, and then applied the same approach to a set of 336 human cDNAs with a success rate of around $60 \%$. This approach allows for optimization of protein purification on a proteome-scale.

\section{References}

1. Proceedings of the National Academy of Sciences, [http://www.pnas.org]

2. Global efforts in structural genomics.

3. Proteome-scale purification of human proteins from bacteria., [http://www.pnas.org/cgi/content/ abstract/99/5/2654]

4. DNA cloning using in vitro site-specific recombination. 